\title{
Heterologous expression of leader-less pga gene in Pichia pastoris: intracellular production of prokaryotic enzyme
}

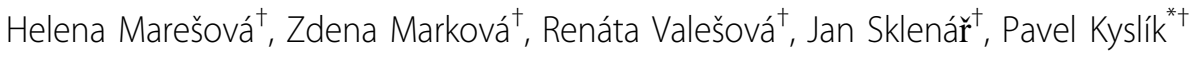

\begin{abstract}
Background: Penicillin G acylase of Escherichia coli (PGA $)$ is a commercially valuable enzyme for which efficient bacterial expression systems have been developed. The enzyme is used as a catalyst for the hydrolytic production of $\beta$-lactam nuclei or for the synthesis of semi-synthetic penicillins such as ampicillin, amoxicillin and cephalexin. To become a mature, periplasmic enzyme, the inactive prepropeptide of PGA has to undergo complex processing that begins in the cytoplasm (autocatalytic cleavage), continues at crossing the cytoplasmic membrane (signal sequence removing), and it is completed in the periplasm. Since there are reports on impressive cytosolic expression of bacterial proteins in Pichia, we have cloned the leader-less gene encoding PGA $A_{E C}$ in this host and studied yeast production capacity and enzyme authenticity.
\end{abstract}

Results: Leader-less pga gene encoding PGA $\mathrm{E}_{\mathrm{EC}} \mathrm{under}$ the control of AOX1 promoter was cloned in Pichia pastoris $X$-33. The intracellular overproduction of heterologous $P G A_{E C}\left(h P G A_{E C}\right)$ was evaluated in a stirred 10 litre bioreactor in high-cell density, fed batch cultures using different profiles of transient phases. Under optimal conditions, the average volumetric activity of $25900 \mathrm{U} \mathrm{I}^{-1}$ was reached. The $\mathrm{hPGA} \mathrm{EC}_{\mathrm{C}}$ was purified, characterized and compared with the wild-type PGA $A_{E C}$. The $\alpha$-subunit of the hPGA $A_{E C}$ formed in the cytosol was processed aberrantly resulting in two forms with C-terminuses extended to the spacer peptide. The enzyme exhibited modified traits: the activity of the purified enzyme was reduced to $49 \%$, the ratios of hydrolytic activities with cephalexin, phenylacetamide or 6-nitro3-phenylacetylamidobenzoic acid (NIPAB) to penicillin G increased and the enzyme showed a better synthesis/ hydrolysis ratio for the synthesis of cephalexin.

Conclusions: Presented results provide useful data regarding fermentation strategy, intracellular biosynthetic potential, and consequences of the heterologous expression of $P G A_{E C}$ in $P$. pastoris $X-33$. Aberrant processing of the precursor of $P G A_{E C}$ in the cytosol yielded the mature enzyme with modified traits.

\section{Background}

Bacterial expression systems enjoy great popularity because of their well-characterized genetics, availability of "taylor-made" cloning vectors as well as hosts, and ability to grow rapidly on inexpensive substrates. These systems are frequently used to construct cell factories for the expression of homologous or heterologous proteins and many industrial production strains were prepared in this way.

\footnotetext{
* Correspondence: kyslik@biomed.cas.cz

† Contributed equally

Laboratory of Enzyme Technology, Institute of Microbiology, wi, Academy of Sciences of the Czech Republic, Vídeňská 1083, 14220 Prague 4, Czech Republic
}

(c) 2010 Marešová et al; licensee BioMed Central Ltd. This is an Open Access article distributed under the terms of the Creative Commons Attribution License (http://creativecommons.org/licenses/by/2.0), which permits unrestricted use, distribution, and reproduction in any medium, provided the original work is properly cited.
Penicillin G acylase (PGA, EC 3.5.1.11) is an excellent example of the commercially valuable enzyme for which a large number of bacterial expression systems was developed [1,2].

The PGAs of E. coli, Arthrobacter viscosus, Providencia rettgeri, Kluyvera citrophila, Bacillus megaterium and Alcaligenes faecalis have been described [3-8] and studied in details regarding the production of $\beta$-lactam nuclei by $\mathrm{N}$-deacylation of penicillin $\mathrm{G}$ or deacetoxycephalosporin G. The same PGAs can be used as potential catalysts for the kinetically controlled synthesis of semisynthetic antibiotics such as ampicillin, amoxicillin, cephalexin, or cefadroxil from the $\beta$-lactam nucleus and appropriate activated acyl donor. The efficiency of the 
synthetic process is generally quantified by the ratio of the rates for the synthetic reaction and hydrolysis of activated acyl donor (ratio $\mathrm{S} / \mathrm{H}$ ): the enzymes with higher value of this parameter are more convenient for a synthetic use [9-11].

Experimental data on the expression of pga gene and posttranslational processing of PGA were obtained predominantly from studies on the PGAs of enterobacteria: the enzyme accumulates in the periplasmic space as a heterodimer and, to become a mature, properly folded enzyme, the precursor peptide has to undergo rather complex processing. The PGA precursor is an inactive prepropeptide that consists of a signal (leader) peptide and a propeptide (spacer) separating $\alpha$ and $\beta$-subunits. Processing of the enzyme precursor in $E$. coli begins in the cytoplasm where the $\beta$-subunit is released by intramolecular autocatalytic cleavage [12]. The signal sequence of the precursor is cleaved upon crossing the cytoplasmic membrane which is followed by an intermolecular, sequential removing of the propeptide generating the $\mathrm{C}$-terminus of the $\alpha$-subunit $[13,14]$. The PGA from gram-positive bacteria such as $B$. megaterium or $A$. viscosus is secreted to the growth medium $[4,15]$.

The expression system based on the methylotrophic yeast Pichia pastoris is another excellent cell factory based on eukaryotic microorganism: the system competes with the prokaryotic one in many aspects, e.g., stable genomic integration of the recombinant expression cassette, high-cell density cultivation, and efficient secretion of the product $[16,17]$. Although the system is predominantly used as a secretory system, efficient cytosolic expression can be achieved. The data on the intracellular expression of bacterial proteins are scarce $[18,19]$. In the case of prokaryotic esterase of Lactobacillus casei, cytosolic expression in Pichia was found to be superior to a prokaryotic expression system: the expression of the esterase was as much as 50 -fold higher in $P$. pastoris X-33 than in E. coli BL2 [19].

The PGA of E. coli was expressed in Saccharomyces cerevisiae: the pga gene was cloned on a multicopy plasmid and the enzyme was secreted to the medium in small amounts [20]. The PGA from $P$. rettgeri secreted by the same host was partially $\mathrm{O}$-glycosylated at the $\alpha$ subunit [21]. This PGA was also cloned and expressed in $P$. pastoris $[22,23]$. The secreted enzyme was entirely $\mathrm{N}$-glycosylated, functional, and exhibited higher thermostability [22]. The extracellular production in a stirred bioreactor reached the volumetric and specific activities of $26500 \mathrm{U} \mathrm{l}^{-1}$ and $18 \mathrm{U} \mathrm{mg}_{\text {protein }}{ }^{-1}$, respectively [23].

So far, the only way of preparation of PGA for industrial use is the expression of the enzyme in prokaryotic hosts. The production capacity for non-glycosylated prokaryotic PGA in Pichia cytosol could be higher but so far this approach has not yet been used.
We have cloned the leader-less gene encoding PGA from E. coli $\left(\mathrm{PGA}_{\mathrm{Ec}}\right)$ under the control of AOX1 promoter in $P$. pastoris $\mathrm{X}-33$. Intracellular expression of the gene was studied in a stirred bioreactor in a high-cell density culture under different profiles of the transient phase applied in the fed-batch process. The heterologous $\mathrm{PGA}_{\mathrm{Ec}}\left(\mathrm{hPGA} \mathrm{Ec}_{\mathrm{Ec}}\right)$ was purified, characterized and compared with the wild-type $\mathrm{PGA}_{\mathrm{Ec}}$ regarding propeptide processing, substrate specificity, physico-chemical traits, kinetic parameters, and kinetically controlled synthesis of $\beta$-lactam antibiotics.

\section{Results}

\section{Cloning of the leader-less pga gene}

The structural gene for PGA $\mathrm{Ec}_{\mathrm{c}}$ (2541 base pairs (bp), including stop codon) encodes the preproprotein with 846 amino acids (aa). Chromosomal DNA from the strain E. coli RE3 was used in PCR reactions to obtain the leader-less pga gene starting from the $79^{\text {th }}$ bp after ATG triplet. In order to express the pga gene in P. pastoris X-33, the upstream PCR primer contained a yeast consensus sequence (with ATG triplet) followed with the first triplet of the $\alpha$-subunit. This construct was inserted into the pPICZ-A under the control of AOX1 promoter and the plasmid was used to transform the host $P$. pastoris $\mathrm{X}-33$. Zeo ${ }^{\mathrm{R}}$ clones identified on selective plates were cultured in shake flasks with methanol and tested for the PGA activity: among 30 clones with $\mathrm{Mut}^{+}$ phenotype, 19 isolates expressed elevated amounts of the PGA ranging from 0.18 to $2.6 \mathrm{U} \mathrm{ml}^{-1}$ after $64 \mathrm{~h}$ of induction. The $\mathrm{Mut}^{+}$isolate with the highest activity was designated as $P$. pastoris $\mathrm{X}-33$ (pPIC-PA1) and selected for further work.

\section{High-cell density culture}

The expression of leader-less pga gene of $E$. coli by eukaryotic system of $P$. pastoris X-33(pPIC-PA1) was studied in a standard, four phase process in a stirred bioreactor. To evaluate the maximum synthetic capacity of the yeast system for the intracellular expression of $\mathrm{hPGA}_{\mathrm{Ec}}$, a transient phase of the process was optimized (the phase required for the transition of cell metabolism from glycerol to methanol in terms of concentration of the methanol as an inducer and profile of the carbon source supplementation).

Four experiments were designed: the cultures with transient profile I (A and B) where continuous induction with methanol ( 0.5 or $1.5 \%)$ was accompanied with linear drop of glycerol feeding to zero; the cultures with the profile II ( $C$ and $D$ ) in which the cultures were starved for glycerol for two hours, and the induction was started with the dose of methanol $(1.5 \%$ or $0.5 \%)$ at the end of the transient phase. In all experiments, the feeding rate of methanol at the methanol feed phase 
was controlled by dissolved oxygen concentration: the process values of $\mathrm{pO}_{2}$ ranged from 5 to $30 \%$.

Samples were taken at regular intervals and the courses of the culture parameters (values of the volumetric activity, specific activity, and cell dry weight concentration) and calculated average final parameters of the cultures are shown in Figure 1 and Table 1.

The highest specific productivities of the $\mathrm{PPGA}_{\mathrm{Ec}} 3.34$ and $2.8 \mathrm{U} \mathrm{g}_{\mathrm{cdw}}{ }^{-1} \mathrm{~h}^{-1}$ were achieved in the experiments $\mathrm{B}$ and $\mathrm{C}$, respectively: the inducer concentration in these cultures equalled $1.5 \%$. In addition, the highest average volumetric activity (25900 $\mathrm{U} \mathrm{l}^{-1}$ ) and specific activity (258 $\mathrm{U} \mathrm{g}_{\mathrm{cdw}}{ }^{-1}$ ) were reached in the experiment $\mathrm{B}$ (the transient phase profile I).

\section{Purification of PGA from E. coli and P. pastoris and determination of authenticity of the heterologous product}

To characterize both PGAs, we purified the wild type PGA from the strain E. coli RE3(pKA18) and hPGA ${ }_{E c}$ from $P$. pastoris X-33(pPIC-PA1). The $\mathrm{PGA}_{\mathrm{Ec}}$ from the prokaryotic host was purified by a purification process consisting of the disintegration of cells, preparation of crude enzyme solution, fractional precipitation, gel filtration, and ion exchange chromatography. The yield of the activity was $20 \%$, the enzyme was purified 29 -fold and had the activity of $64.6 \mathrm{U} \mathrm{mg}_{\text {protein }}{ }^{-1}$. Purity control of the isolated PGA $\mathrm{Ec}_{\mathrm{Ec}}$ by SDS-PAGE electrophoresis revealed two protein bands with molecular weights corresponding to $\alpha$ and $\beta$-subunits. Calculated molecular weights from MALDI-TOF MS data of PGA $\mathrm{Ec}_{\mathrm{Ec}}$ were 23.8 and $62.4 \mathrm{kDa}$ for $\alpha$ and $\beta$-subunits, respectively, and corresponded to theoretical values of 23.8 and $62.4 \mathrm{kDa}$ (Figure 2).

To isolate the $\mathrm{hPGA}_{\mathrm{Ec}}$ from P. pastoris $\mathrm{X}-33$ (pPICPA1), crude enzyme solution was prepared by disintegration of the biomass from the fed-batch experiment $B$. The inhibitors of proteases in the course of hPGA $\mathrm{Ec}_{\mathrm{c}}$ purification were used to exclude any further non-specific proteolysis of the enzyme.
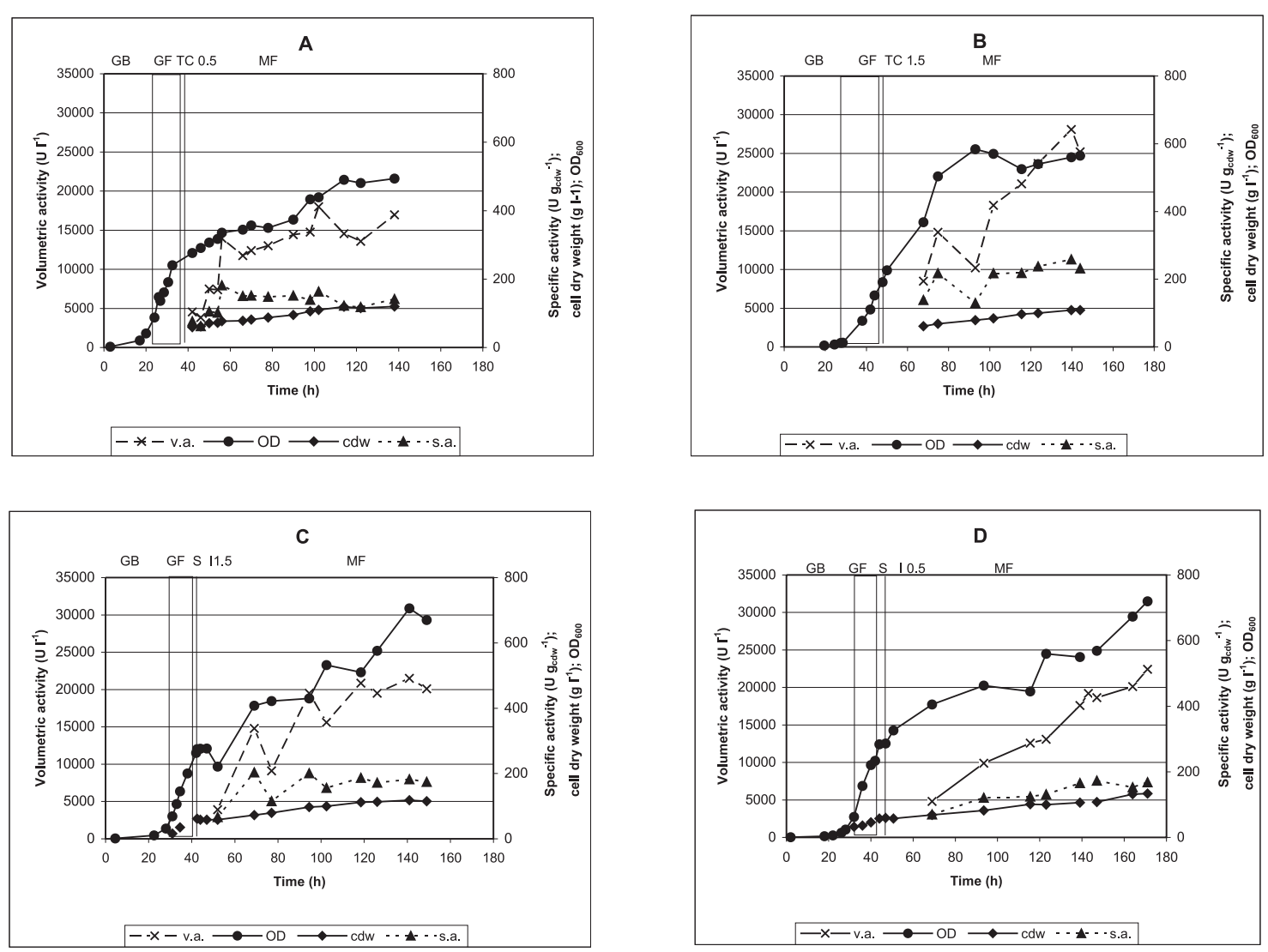

Figure 1 The effect of transient phase profile on $\mathrm{hPGA}$ Ec production in fed-batch cultures of the strain P. pastoris X-33(pPIC-PA1). Time courses of the values of the cell dry weight $\left(\mathrm{g}^{-1}\right)$, optical density $\left(\mathrm{OD}_{600}\right)$, volumetric activity $\left(\mathrm{U}^{-1}\right)$ and specific activity of $h P G A_{E C}\left(U g_{C d w}{ }^{-1}\right)$ assayed in the cultures in a 10- I stirred bioreactor. Phases of the cultures: GB, glycerol batch culture; GF, glycerol feed culture; TC, transient phase with linear decrease of glycerol concentration to 0 and constant feed of methanol (A- final concentration of methanol $0.5 \%$, B- final concentration of methanol 1.5\%); SI, transient phase with starvation for glycerol and single dose of methanol at the end of the phase (C- final concentration of methanol 1.5\%, D- final concentration of methanol $0.5 \%$ ); MF, methanol feed culture. 
Table 1 The effect of the transient phase profile on parameters of the fed-batch culture of $P$. pastoris X-33(pPIC-PA1) in a 10-I stirred bioreactor

\begin{tabular}{lllllllll}
\hline $\begin{array}{l}\text { TP profile - } \\
\text { Experiment }\end{array}$ & Methanol & $\begin{array}{l}\text { Maximal } \\
\text { volumetric } \\
\text { activity }(\mathrm{h})^{*}\end{array}$ & $\begin{array}{l}\text { Specific } \\
\text { activity }\end{array}$ & $\begin{array}{l}\text { Cell dry } \\
\text { weight }\end{array}$ & $\begin{array}{l}\text { Average } \\
\text { volumetric } \\
\text { activity }\end{array}$ & $\begin{array}{l}\text { Average } \\
\text { cell dry } \\
\text { weight }\end{array}$ & $\begin{array}{l}\text { Induction } \\
\text { time }\end{array}$ & $\begin{array}{l}\text { Specific } \\
\text { productivity }\end{array}$ \\
\hline & $(\%)$ & $\left(\mathrm{U} \mathrm{l}^{-1}\right)(\mathrm{h})$ & $\left(\mathrm{U} \mathrm{g} \mathrm{gdw}^{-1}\right)$ & $\left(\mathrm{g} \mathrm{I}^{-1}\right)$ & $\left(\mathrm{U} \mathrm{I}^{-1}\right)$ & $\left(\mathrm{g} \mathrm{I}^{-1}\right)$ & $(\mathrm{h})$ & $\left(\mathrm{U} \mathrm{g}_{\mathrm{cdw}}{ }^{-1} \mathrm{~h}^{-1}\right)$ \\
\hline I- A & 0.5 & $18000(102)$ & 163 & 120 & 16000 & 120 & 79 & 1.68 \\
I- B & 1.5 & $28100(140)$ & 258 & 109 & 25900 & 106 & 73 & 3.34 \\
II - C & 1.5 & $21500(140)$ & 182 & 115 & 20510 & 115 & 63 & 2.8 \\
II - D & 0.5 & $22420(170)$ & 167 & 130 & 20400 & 124 & 100 & 1.64 \\
\hline
\end{tabular}

TP profile - transient phase profile: I - linear feeding of methanol, linear decrease of glycerol feeding, II - starvation for glycerol; methanol supplemented at the end of the transient phase in a single dose. Methanol - final concentration at the beginning of methanol feeding phase. ${ }^{*}(\mathrm{~h})$ means the hour at which maximal volumetric activity was achieved. Average volumetric activity - volumetric activity calculated from the last three values of activity assay. Induction time - time of growth on methanol required to achieve the average activity.

SDS-PAGE gel analysis after each purification step showed that the enzyme was sufficiently pure after the purification step on DEAE fractogel. The enzyme was purified 26-fold with an overall activity yield of $46 \%$ and had the activity of $31.8 \mathrm{U} \mathrm{mg}_{\text {protein }}{ }^{-1}$. SDS-PAGE gel electrophoresis revealed presence of two forms of the $\alpha$-subunit: $\alpha_{1}(36 \%)$ and $\alpha_{2}(64 \%)$. Molecular weights calculated from MALDI-TOF MS data were 24.0, 25.9 and 62.4 kDa for $\alpha_{2}, \alpha_{1}$, and $\beta$-subunit, respectively (Figure 2 ).

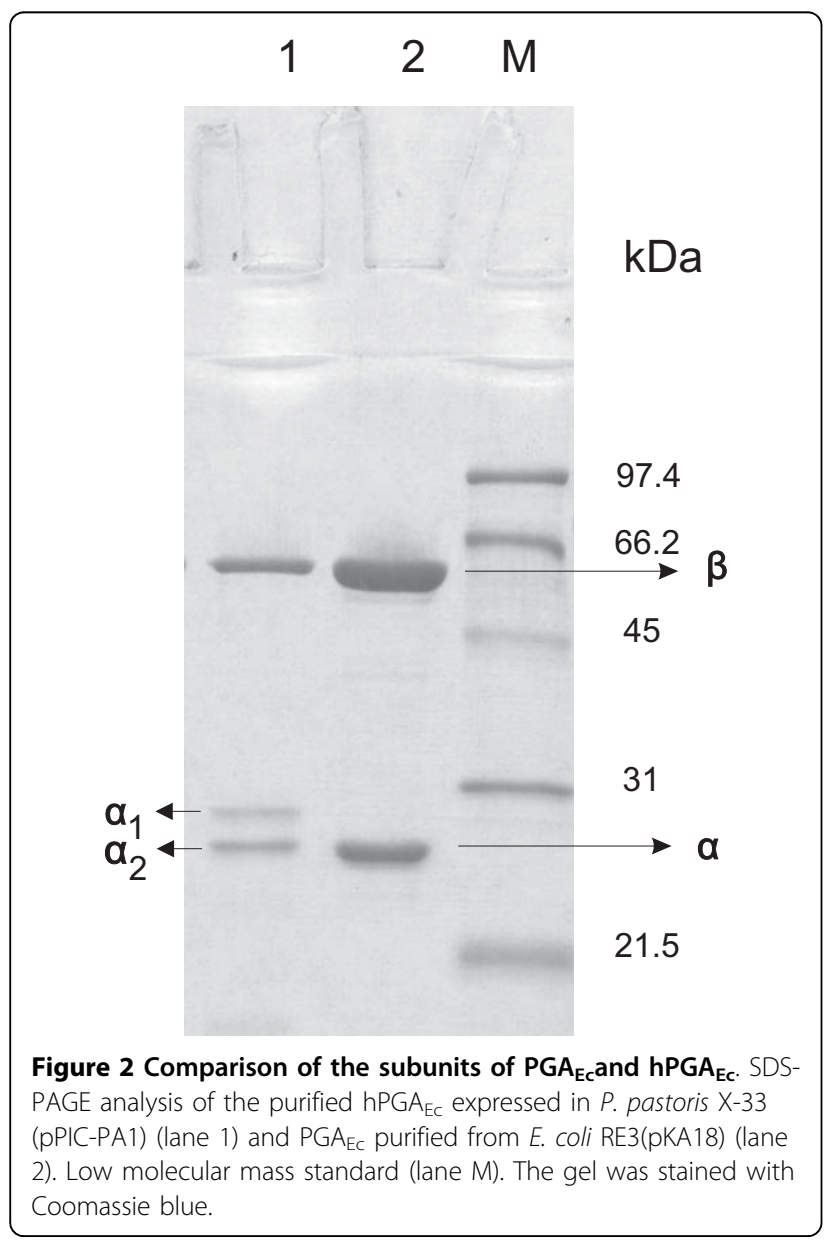

Comparison of MALDI-TOF MS analysis of tryptic digests of the $\alpha$-subunit from $E$. coli and $\alpha_{1}, \alpha_{2}$-subunits from $P$. pastoris $\mathrm{X}-33$ revealed differences in primary structures: the $\mathrm{C}$-terminus of the $\alpha_{2}$-subunit extends to the amino acid residue $A_{210}$ of the spacer peptide (extension by $1 \mathrm{aa}$ ) and the $\mathrm{C}$-terminus of the $\alpha_{1}$ extends to $K_{227}$ of the spacer (extension by $18 \mathrm{aa}$ ). The C-terminus of the $\alpha$-subunit from $\mathrm{PGA}_{\mathrm{Ec}}$ is formed by $\mathrm{A}_{209}$. The $\mathrm{N}$-terminus was investigated according to the modified protocol based on the use of the reagent 4-sulfophenyl-isothiocyanate (SPITS) before protein separation by SDS-PAGE electrophoresis. Analysis of the labelled $\mathrm{N}$-terminus confirmed that the terminuses of $\alpha_{1}$ and $\alpha_{2}$-subunits of $\mathrm{hPGA} \mathrm{Ec}_{\mathrm{Ec}}$ start with methionine which is missing in the mature form of $\mathrm{PGA}_{\mathrm{Ec}}$. As regards the $\beta$-subunits of $\mathrm{PGA}_{\mathrm{Ec}}$ and $\mathrm{hPGA} \mathrm{Ec}_{\mathrm{c}}$, they were identical.

\section{Physico-chemical and kinetic parameters of PGA $A_{E c}$ and hPGA ${ }_{E c}$}

Hydrolytic activities of both purified PGAs were determined with penicillin $\mathrm{G}$, penicillin $\mathrm{V}$, ampicillin, amoxicillin, cephalexin, 6-nitro-3-phenylacetylamidobenzoic acid (NIPAB), and phenylacetamide (Figure 3). It is evident that the enzymes differ in the substrate specificity: in terms of a hydrolytic activity ratio, they have the same values for penicillin $\mathrm{V}$, ampicillin or amoxicillin to penicillin $\mathrm{G}$. The increased ratio of the hydrolysis of cephalexin, phenylacetamide or NIPAB to penicillin G was observed with $\mathrm{hPGA}_{\mathrm{Ec}}$ and the value ranged from $50 \%$ (cephalexin) to $200 \%$ (NIPAB).

Stability of the hydrolytic activity (the effect of the temperature or $\mathrm{pH}$ ), temperature optimum and $\mathrm{pH}$ optimum of the enzyme were determined for both enzymes with penicillin $G$ as the reaction substrate. It was found that $\mathrm{PGA}_{\mathrm{Ec}}$ exhibited high stability in the range of $\mathrm{pH}$ from 3 to 8.5 , while $\mathrm{hPGA} \mathrm{Ec}_{\mathrm{Ec}}$ is stable only in the range of $\mathrm{pH}$ from 4 to 8 . The activity of the heterologous enzyme dropped by $15-20 \%$ at $\mathrm{pH} 3.5$ and 8.5. The remaining activity of $50 \%$ was assayed at $\mathrm{pH}$ values 3 and 9 . 


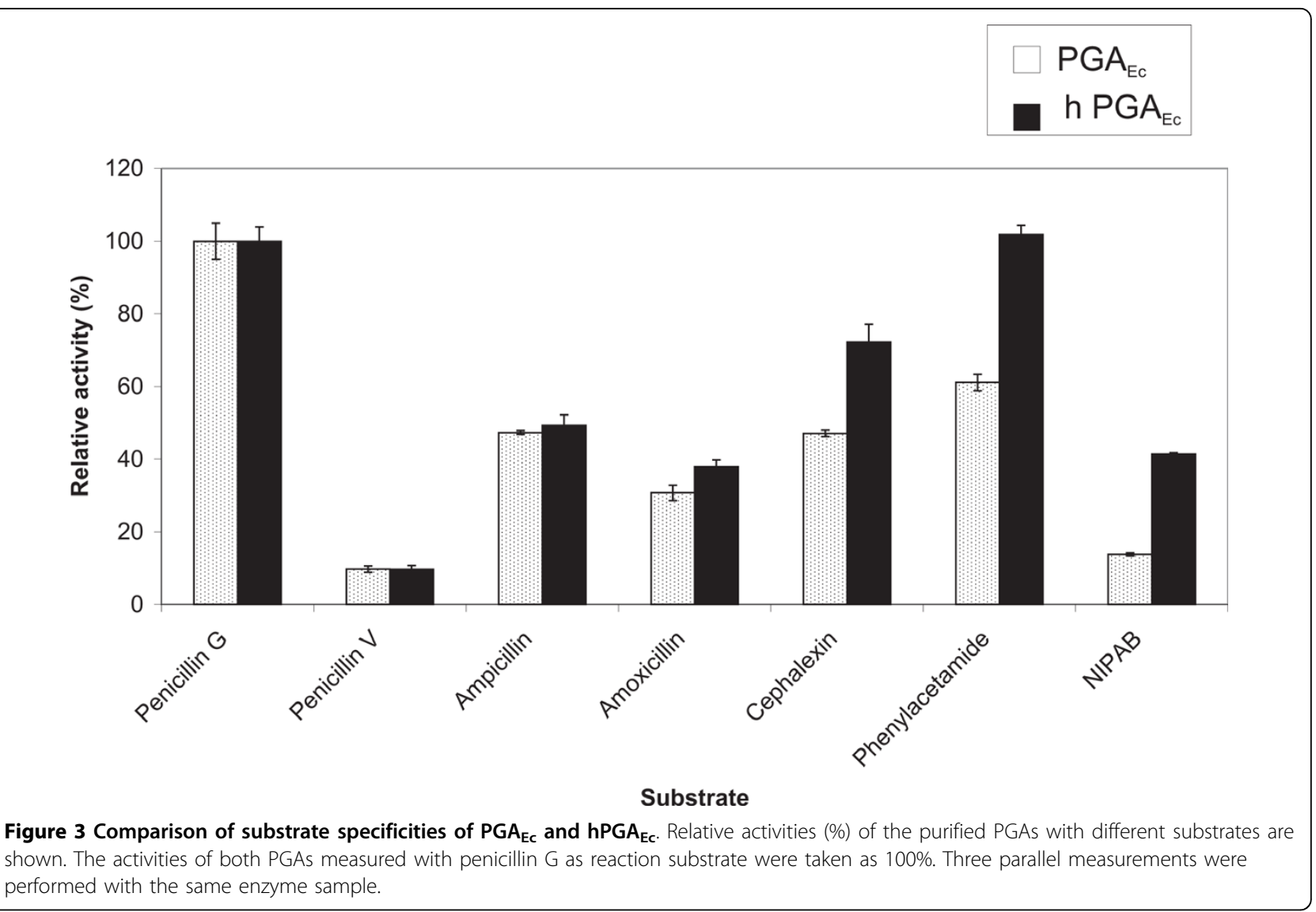

The effect of the temperature on the stability of the enzymes was studied in the range of temperatures from 20 to $70^{\circ} \mathrm{C}$. Both enzymes were stable up to $40^{\circ} \mathrm{C}$. At higher pre-incubation temperatures, the remaining activities of both enzymes fell down rapidly.

Determination of the $\mathrm{pH}$ and temperature optima suggested that the temperature and $\mathrm{pH}$ optimum for the hydrolytic activity of $\mathrm{PGA}_{\mathrm{Ec}}$ and $\mathrm{hPGA} \mathrm{Ec}_{\mathrm{Ec}}$ were $55^{\circ} \mathrm{C}, \mathrm{pH}$ 8.0 and $50^{\circ} \mathrm{C}, \mathrm{pH} 7.5$, respectively.

The kinetic parameters were determined with the natural substrate penicillin $G$ and chromogenic substrate NIPAB. The initial reaction rate of the hydrolysis of the substrate was measured in the range of substrate concentrations: 5-100 $\mu \mathrm{M}$ for penicillin $\mathrm{G}$ and 7-2000 $\mu \mathrm{M}$ for NIPAB. The values of $K_{\mathrm{m}}, k_{\mathrm{cat}}$ and $V_{\max }$ of $\mathrm{PGA}_{\mathrm{Ec}}$ and $\mathrm{hPGA}_{\mathrm{Ec}}$ are shown in Table 2.

Table 2 Kinetic parameters of PGA $A_{E c}$ and hPGA

\begin{tabular}{lllll}
\hline Enzyme & Substrate & $\begin{array}{l}\boldsymbol{K}_{\boldsymbol{m}} \\
(\boldsymbol{\mu M})\end{array}$ & $\begin{array}{l}\boldsymbol{V}_{\max } \\
\left(\boldsymbol{\mu} \mathbf{m o l} \mathbf{~ m i n}^{-\mathbf{1}} \mathbf{~ m l}^{\mathbf{- 1}}\right)\end{array}$ & $\begin{array}{l}\boldsymbol{k}_{\text {cat }} \\
\left(\mathbf{s}^{-1}\right)\end{array}$ \\
\hline $\mathrm{PGA}_{\mathrm{EC}}$ & penicillin G & 34 & 121 & 13.6 \\
& NIPAB & 28 & 15 & 1.6 \\
$\mathrm{hPGA}_{\mathrm{EC}}$ & penicillin G & 12 & 7.7 & 6.4 \\
& NIPAB & 30 & 2.6 & 2.2 \\
\hline
\end{tabular}

To check if the aberrant processing of hPGA $\mathrm{Ec}_{\mathrm{c}}$ could result in improved traits of the enzyme in syntheses of $\beta$-lactam antibiotics, kinetically controlled syntheses of cephalexin, amoxicillin and ampicillin catalyzed by both purified PGAs were carried out at $\mathrm{pH} 7.0$ and $30^{\circ} \mathrm{C}$. We found that the $\mathrm{S} / \mathrm{H}$ ratios for the enzymatic formation of cephalexin by $\mathrm{PGA}_{\mathrm{Ec}}$ and $\mathrm{hPGA} \mathrm{Ec}_{\mathrm{E}}$ were 2.6 and 3.9, respectively. Both enzymes $\mathrm{PGA}_{\mathrm{Ec}}$ and $\mathrm{hPGA} \mathrm{Ec}_{\mathrm{Ec}}$ have similar $\mathrm{S} / \mathrm{H}$ ratios for the synthesis of ampicillin from 6aminopenicillanic acid (6-APA) and D-phenylglycine amide (1.7 and 1.9), and amoxicillin from 6-APA and D-p-hydroxyphenylglycine amide (1.1 and 1.0).

\section{Discussion}

At present, production strains for PGA used in industry are mainly the recombinant strains of $E$. coli based on a homologous cloning of the genes: the same microorganism is used as the pga gene donor and the host for the recombinant plasmid. The finding that penicillin acylases may also catalyze syntheses of $\beta$-lactam antibiotics (e.g., ampicillin, amoxicillin, cephalexin etc.) started the search for "novel" or "improved" penicillin acylases with more convenient traits for these synthetic applications [24]. The development of the eukaryotic expression system based on P. pastoris and "bio-sourcing" of the genes 
from the environmental DNA revealed an underestimated aspect of the expression of the cloned gene in a foreign host: an authenticity of the heterologous protein.

To evaluate the production potential of $P$. pastoris X-33 for intracellularly expressed $\mathrm{PGA}_{E c}$, the leader-less pga gene was integrated into the chromosome of $P$. pastoris X-33 and the $\mathrm{Mut}^{+}$strain $P$. pastoris X-33(pPICPA1) was constructed. The gene was not adapted to $P$. pastoris codon usage and its intracellular expression induced with methanol was studied in a stirred bioreactor in high-cell density cultures. The effect of the profile of the transient phase of the fed-batch culture on penicillin acylase production was selected as the parameter for the optimization of the fermentation process. It can be concluded that the change of glycerol to methanol utilization during the transient phase had a marked effect on the volumetric activity and specific productivity of the culture: a continuous decrease of glycerol accompanied with linear increase of the methanol concentration (up to 1.5\%) resulted in the highest values of both parameters.

When the production capacity for the homologous $\mathrm{PGA}_{\mathrm{Ec}}$ was studied in a fed-batch culture of the recombinant $E$. coli, the specific activity of about $900 \mathrm{U} \mathrm{g}_{\mathrm{cdw}}{ }^{-1}$ was reached [25] which corresponded to the volumetric activity of about 14000-22000 $\mathrm{U} \mathrm{l}^{-1}$ (the scale-up of fermentation to a 300-l bioreactor) [26]. In our experiments, the volumetric activity of hPGA $\mathrm{Ec}_{\mathrm{E}}$ expressed in $P$. pastoris $\mathrm{X}-33$ after induction with $1.5 \%$ methanol reached higher level and ranged from 25000 to $28000 \mathrm{U}$ $\mathrm{l}^{-1}$. However, the specific activity was lower in comparison with the bacterial culture.

The finding that the activity of the purified enzyme $\mathrm{hPGA}_{\mathrm{Ec}}$ is low (about $31 \mathrm{U} \mathrm{mg}_{\text {protein }}{ }^{-1}$ ) was surprising. Considering the pattern of the subunit bands on SDS gel, we have concluded that $\mathrm{hPGA}_{\mathrm{Ec}}$ is not correctly maturated in the cytosol of $P$. pastoris X-33 and the enzyme is a mixture of two isoforms in the ratio $1\left(\alpha_{1} \beta\right)$ to $2\left(\alpha_{2} \beta\right)$. As expected, we have proved by deglycosylation experiment (data not shown), that no $\mathrm{N}$-glycosylation occurred as it was described for the secreted enzyme of $P$. rettgeri in P. pastoris GS115 [22]. The authors reported 3 types of the $\beta$-subunit and 2 forms of the $\alpha$-subunit: while the $\beta$-subunit was glycosylated to a different extent (three bands), two bands of the $\alpha$ subunit were formed due to non-specific proteolysis at the $\mathrm{N}$-terminus of the subunit. However, the $\mathrm{C}$-terminus of the smaller subunit was not analyzed.

In our case, different processing occurred in the cytosol at this very terminus. Amino acid sequence analysis of the $\mathrm{N}$ - and $\mathrm{C}$-terminuses confirmed that the $\beta$-subunits of PGA $\mathrm{Ec}_{\mathrm{c}}$ and $\mathrm{hPGA} \mathrm{Ec}_{\mathrm{Ec}}$ are identical and that the first step of the precursor maturation, an autocatalytic cleavage between the spacer peptide and $\beta$-subunit, occurs correctly in the cytosol. This finding is in agreement with autocatalytic intracellular processing and the $\mathrm{N}$-terminus formation of the $\beta$-subunit found in prokaryotes [14].

At present, we have no piece of evidence if the hostor non-specific proteolysis is involved in processing of the hPGA ${ }_{\mathrm{Ec}}$ precursor consisting of the $\alpha$-subunit and propeptide. It is known that the $\alpha$-subunit of PGA is responsible for the substrate specificity of the enzyme [27]. Modified primary structures of the $\alpha$-subunits can explain the lower activity of purified $\mathrm{hPGA}_{\mathrm{Ec}}$ expressed in the cytosol of $P$. pastoris X-33: the $\alpha$-subunits start with methionine and their $\mathrm{C}$-terminuses extend to $\mathrm{A}_{210}$ of the spacer peptide (extension by 1 aa, $\alpha_{2}$-subunit) or $K_{227}$ (extension by 18 aa, $\alpha_{1}$-subunit).

In terms of biosynthetic potential of the cell for the properly matured enzyme, the volumetric activity and specific activity of hPGA $\mathrm{Ec}_{\mathrm{cc}}$ would correspond to about $52000 \mathrm{U} \mathrm{l}^{-1}$ and $516 \mathrm{U} \mathrm{g}_{\mathrm{cdw}}{ }^{-1}$, respectively, because the ratio of the activity of purified $\mathrm{PGA}_{\mathrm{Ec}}$ to $\mathrm{hPGA} \mathrm{Ec}_{\mathrm{Ec}}$ equals about two.

A presence of several mature forms of the periplasmic PGA from A. faecalis expressed in E. coli was also described [28] and the results were discussed in terms of the conversion of the N-terminal glutamine to pyrrolidone carboxylic acid and the loss of three aa from the C-terminus of the $\alpha$-subunit.

It is evident [[22,23,28] our results], that heterologous expression of PGA may yield a mature enzyme with modified primary structure and traits.

A hydrolysis of selected substrates is an important parameter for evaluation of any changes in the substrate specificity of the heterologous enzyme that may have occurred at the expression in a given host. The hPGA $\mathrm{Ec}_{\mathrm{Ec}}$ has got higher affinity to cephalexin (substrate with 7aminodeacetoxycephalosporanic acid moiety, 7-ADCA), phenylacetamide and NIPAB (a chromogenic synthetic substrate based on nitrobenzoic acid). There was no change in the enzyme affinity to the substrates containing 6-APA moiety. Regarding the kinetic parameters determined with the natural substrate penicillin G, aberrant maturing of hPGA $\mathrm{Ec}_{\mathrm{Ec}}$ resulted in lower $K_{\mathrm{m}}, V_{\text {max }}$ and $k_{c a t}$.

Compared to the properly matured enzyme, the $\mathrm{S} / \mathrm{H}$ ratio of $h P G A_{E c}$ for the synthesis of cephalexin was increased by $50 \%$. Improvement of PGA traits as regards the synthesis of cephalexin was described for a chimeric penicillin acylase. After shuffling of the pga genes of $E$. coli, $P$. rettgeri and $K$. cryogenes, the mutant enzyme displayed a $40 \%$ higher synthetic activity than the wild type enzyme of $P$. rettgeri [29].

The $\mathrm{pH}$ and temperature stabilities of both enzymes are comparable with literature data $[30,31]$ and the heterologous expression in $P$. pastoris X33 system has no marked effect on these parameters. 


\section{Conclusions}

The prokaryotic, leader-less gene encoding PGA $_{\mathrm{Ec}}$ under the control of AOX1 promoter can be efficiently expressed in the cytosol of the yeast $P$. pastoris X-33. The activity of the mature enzyme equals $31.8 \mathrm{U}$ mg tein $^{-1}$ and this value corresponds to $49 \%$ of the $\mathrm{PGA}_{\mathrm{Ec}}$ activity. It was shown that the precursor of $\mathrm{hPGA} \mathrm{Ec}_{\mathrm{Ec}}$ was processed aberrantly and the enzyme exhibited improved traits for the synthesis of cephalexin, a $\beta$-lactam antibiotic containing 7-ADCA moiety. No improvement was observed in syntheses of the antibiotics derived from 6-APA. The understanding on structure/ function relationships of the aberrantly processed or engineered propeptide of a penicillin acylase could be applicable to modify the traits of the enzyme.

\section{Methods}

\section{Strains and expression constructs}

The construction of the strains E. coli RE3 (CCM 4228) and RE3(pKA18) have been described earlier [2,32].

The leader-less $p g a$ gene was amplified in two steps by two PCR using the chromosomal DNA of the strain $E$. coli RE3 as a template. An upstream primer 5'-AGCGGTGAATAAAGCGATTCGTTT derived from a flanking part of 5 'end of $p g a$ gene and a downstream primer 5'-TTTCGGGCCCAATTATCTCTCTGAAC were used in the first PCR reaction (the ApaI restriction site is highlighted in bold). The specific product from the first PCR reaction was used as a template in the second PCR reaction with pair of primers: upstream primer 5'-ATAATGGAGCAGTCGTCAA-GTGAG (a part of yeast consensus sequence is highlighted in bold) and the same downstream primer as in the first PCR reaction. The specific PCR product was cloned into PmlI/ApaI restriction sites of the vector pPICZ-A (Invitrogen). The constructed plasmid was designated as pPIC-PA and used to transform the host E. coli TOP10. Plasmid bearing the leader-less $p g a$ gene from Zeo ${ }^{\mathrm{R}}$ transformant was linearized by SacI and transformed by electroporation into the host $P$. pastoris X-33. All routine techniques for DNA manipulations were performed as described previously [33].

\section{Media and flasks cultures}

E. coli strains were cultured in low-salt Luria-Bertani (LB) medium at $37^{\circ} \mathrm{C}$. If required, Zeocin $\left(25 \mu \mathrm{g} \mathrm{ml}^{-1}\right)$ was supplemented. $P$. pastoris $\mathrm{X}-33$ was cultured in $\mathrm{YP}$ medium (1\% yeast extract, $2 \%$ peptone) supplemented with $2 \%$ glucose (YPD medium) or $2 \%$ glycerol (YPGly medium). Solid YPDS medium (1\% yeast extract, $2 \%$ peptone, $2 \%$ glucose, $1 \mathrm{M}$ sorbitol, $2 \%$ agar, and 100 , 200, 500 or $1000 \mu \mathrm{g}$ of Zeocin per $\mathrm{ml}$ ) was used for selection of the yeast transformants.

\section{Screening for $\mathrm{Zeo}^{\mathrm{R}}$ positive clones}

A screening was carried out on solid YPDS medium supplemented with Zeocin $\left(100 \mu \mathrm{g} \mathrm{ml}^{-1}\right)$ after incubation for 3 days at $28^{\circ} \mathrm{C}$. Subsequent selection of 150 $\mathrm{Zeo}^{\mathrm{R}}$ isolates was carried out using replica plating on solid YPD medium containing 200, 500 or $1000 \mu \mathrm{g} \mathrm{ml}^{-1}$ of Zeocin. Thirty clones from the plates with the highest concentration of Zeocin were grown in $10 \mathrm{ml}$ of YPGly medium with biotin $\left(4 \times 10^{-5} \%\right)$ for $16 \mathrm{~h}$ at $28^{\circ} \mathrm{C}$. Each culture was centrifuged at room temperature, the cell pellet was resuspended in $20 \mathrm{ml}$ of YP medium to get $\mathrm{OD}_{600}$ of 1.0 and methanol was added to a final concentration of $0.5 \%$ to induce the enzyme synthesis. Every 24 hours, an equal dose of methanol was added to maintain the culture growth for 64 hours. Cultures were sampled at given intervals for the enzyme assay.

\section{High-cell density culture in stirred bioreactor}

The fed-batch culture was carried out in a stirred bioreactor Biostat MD (B. Braun Biotech International, Melsungen, Germany) with initial working volume of 6 litres at $28^{\circ} \mathrm{C}$. The batch culture medium contained per litre: $6 \mathrm{~g} \mathrm{KOH}, 10 \mathrm{~g} \mathrm{MgSO}_{4} .7 \mathrm{H}_{2} \mathrm{O}, 1.3 \mathrm{~g} \mathrm{KI}, 40 \mathrm{ml}$ glycerol and $10 \mathrm{ml}$ of $85 \% \mathrm{H}_{3} \mathrm{PO}_{4}$. Solution of $\mathrm{CaSO}_{4}(1.3$ g) and biotin $\left(0.4 \mathrm{mg} \mathrm{l}^{-1}\right.$ of medium) were sterilized separately. PTM1 trace salt stock solution contained per

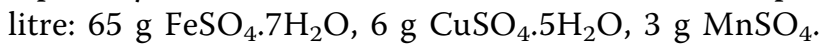
$\mathrm{H}_{2} \mathrm{O}, 20 \mathrm{~g} \mathrm{ZnCl}_{2}, 0.2 \mathrm{~g} \mathrm{Na}_{2} \mathrm{MoO}_{4} \cdot 2 \mathrm{H}_{2} \mathrm{O}, 0.8 \mathrm{~g} \mathrm{KI}, 0.2 \mathrm{~g}$ $\mathrm{H}_{3} \mathrm{BO}_{3}, 0.5 \mathrm{~g} \mathrm{CaSO}_{4} .2 \mathrm{H}_{2} \mathrm{O}, 5 \mathrm{ml}$ of concentrated $\mathrm{H}_{2} \mathrm{SO}_{4}$, and was added to the medium after sterilization ( $2 \mathrm{ml}$ per litre of the medium). Two feeding solutions were prepared: glycerol (50\% water solution) and methanol ( $99.5 \%$ solution). Both solutions were supplemented with trace metals and biotin in amounts stated above. The airflow was kept constant at the maximum of the system (10 litres of air per minute) and the $\mathrm{pH}$ of the culture was controlled at 5.0 by $\mathrm{NH}_{4} \mathrm{OH}$ (25\% water solution). A concentration of dissolved oxygen $\left(\mathrm{pO}_{2}\right)$ was maintained at $30 \%$ of the value for air saturation of the medium by cascade regulation of stirring frequency in the course of the initial batch phase. The glycerol as well as methanol feeding was controlled by the value of $\mathrm{pO}_{2}$ that was set up to the value of $30 \%$.

The flask inoculum (10 $\mathrm{ml}$ of YPGly medium) was inoculated with a single colony from agar plate with YPD medium and cultured on orbital shaker for 20 hours at $28^{\circ} \mathrm{C}$. Two $\mathrm{ml}$ of the culture were transferred to $100 \mathrm{ml}$ of YPGly medium, the flask was cultured for 24 hours at $28^{\circ} \mathrm{C}$ and the whole culture was used to seed the medium in a bioreactor. A standard fed-batch process consisting of four phases was used to express the heterologous pga gene: phase 1 - a batch culture in the medium supplemented with glycerol (about $40 \mathrm{~h}$ ); 
phase 2 - feeding of glycerol to reach high concentration of the biomass (OD of about 280); phase 3 - transition of the cell metabolism from glycerol to methanol (90 $120 \mathrm{~min}$ ), and phase 4 - induction of the enzyme expression by feeding of methanol.

To maximize the production of $\mathrm{hPGA}_{\mathrm{Ec}}$, two strategies dealing with the phase 3 were applied. Profile I: a linear increase of methanol concentration in the course of the transition phase up to 0.5 and $1.5 \%$ in experiment $\mathrm{A}$ and $B$, respectively, accompanied simultaneously with linear decrease of glycerol feeding rate to zero. Profile II: the culture was starved in the course of the transient phase both for glycerol and methanol; after $120 \mathrm{~min}$, methanol was added in a single dose to reach final concentration of 1.5 and $0.5 \%$ in experiment $C$ and $D$, respectively.

\section{Assay of hydrolytic activity}

The biomass from 1-ml samples of a culture was separated by centrifugation and rinsed with distilled water. The pellet was resuspended in $1 \mathrm{ml}$ of $0.1 \mathrm{M}$ sodium phosphate buffer ( $\mathrm{pH} 8.0$ ), $1.25 \mathrm{ml}$ of glass beads were added (diameter of $0.5 \mathrm{~mm}$, Willy A. Bachofen AG. Basel, Switzerland), and the cells were mechanically disrupted by vortexing for $20 \mathrm{~min}$. The debris of cells was removed by centrifugation and the activity of PGA was measured in the supernatant. The activity of PGA was assayed in $0.05 \mathrm{M}$ sodium phosphate buffer $(\mathrm{pH} 8.0)$ supplemented with penicillin $\mathrm{G}$ ( $2 \%$ solution) using the method described by [34]. The activity of one unit (U) is defined as the amount of PGA producing $1 \mu \mathrm{mol}$ of 6-APA $\mathrm{min}^{-1}$ at $37^{\circ} \mathrm{C}$. The specific activity is expressed in $\mathrm{U}$ per $\mathrm{g}$ of cell dry weight $(\mathrm{cdw})$.

Hydrolysis of substrates (penicillin G, penicillin V, ampicillin, amoxicillin, cephalexin, NIPAB and phenylacetamide; concentration of $0.5 \%$ ) was carried out in 50 mM phosphate buffer, pH $7.5\left(\mathrm{hPGA}_{\mathrm{Ec}}\right)$ or 8 (PGA Ec $)$ at $37^{\circ} \mathrm{C}$. The resulting 6 -APA and 7 -ADCA were monitored by spectrophotometer at $415 \mathrm{~nm}$ after coupling with p-dimethylaminobenzaldehyde [34]. Determination of the activity with phenylacetamide was based on the measurement of liberated ammonia [35]. Hydrolysis of NIPAB was measured by spectrophotometer according to [3]. The molar extinction coefficient for 3-amino-6nitrobenzoic acid $\left(\varepsilon_{405}\right)$ equalled $9.09 \mathrm{mM}^{-1} \mathrm{~cm}^{-1}$. The activity of one unit (U) was defined as the amount of the enzyme that hydrolyzed $1 \mu \mathrm{mol}$ of NIPAB per min in $50 \mathrm{mM}$ phosphate buffer, $\mathrm{pH} 7.5\left(\mathrm{hPGA}_{\mathrm{Ec}}\right)$ or 8 $\left(\mathrm{PGA}_{\mathrm{Ec}}\right)$ at $37^{\circ} \mathrm{C}$.

\section{Enzyme purification}

Biomass (50 g wet weight) of the strain E. coli RE3 (pKA18) from 21 of fermentation broth obtained as described earlier [32] was disintegrated and cell-free enzyme extract was prepared by thermal treatment in the presence of polyethyleneimine $\left(45^{\circ} \mathrm{C}, \mathrm{pH} 5.0\right)$. PGA was precipitated with ammonium sulphate from $50 \mathrm{ml}$ of the enzyme extract at concentration between 40-60\% of sulphate saturation. The precipitate was collected by centrifugation $\left(5000 \mathrm{~g}, 35 \mathrm{~min}, 4^{\circ} \mathrm{C}\right)$, dissolved in 10 $\mathrm{mM}$ phosphate buffer ( $\mathrm{pH} 8.0$ ), dialyzed against the same buffer and the enzyme solution was applied to a DEAE-fractogel EMD 6500(S) column. The elution was carried out with the same buffer. The fractions having the activity of PGA were pooled and dialyzed against 1 $\mathrm{mM}$ phosphate buffer ( $\mathrm{pH}$ 7.0). The enzyme solution was applied to a hydroxyapatite column equilibrated with $1 \mathrm{mM}$ phosphate buffer $(\mathrm{pH} 7.0)$ and PGA was eluted using a linear gradient $0-100 \%$ of $200 \mathrm{mM}$ phosphate buffer. The pooled fractions were concentrated by utrafiltration on Amicon 8010 and washed with 150 $\mathrm{mM} \mathrm{NaCl}$ in $50 \mathrm{mM}$ phosphate buffer ( $\mathrm{pH} 7.5$ ). The enzyme solution was applied to a Superdex 200 column equilibrated with $50 \mathrm{mM}$ phosphate buffer ( $\mathrm{pH}$ 7.0) containing $150 \mathrm{mM} \mathrm{NaCl}$. PGA was eluted from the column and the pooled fractions were ultrafiltrated on Amicon 8010, washed as described above and stored at $-20^{\circ} \mathrm{C}$.

The hPGA $\mathrm{Ec}_{\mathrm{E}}$ from $P$. pastoris X-33(pPIC-PA1) was purified from $11.8 \mathrm{~g}$ wet weight of the biomass from the experiment B: the biomass was resuspended in $50 \mathrm{ml}$ of $0.1 \mathrm{M}$ sodium phosphate buffer $(\mathrm{pH} 8.0)$ with $0.5 \mathrm{ml}$ of Protease Inhibitor Cocktail (Sigma). $50 \mathrm{ml}$ of glass beads were added to disrupt the cells on Lab-Shaker (A. Kühner AG, Switzerland) at $330 \mathrm{rpm}$ for $1 \mathrm{~h}$. After centrifugation (10000 g, $20 \mathrm{~min}, 4^{\circ} \mathrm{C}$ ), CYSEP 329 (CYTEC Industries BV, Netherlands) was added to the supernatant up to the final concentration of $7.5 \%$. Precipitated bulk protein was separated by centrifugation and PGA in the supernatant was precipitated with ammonium sulphate (up to $50 \%$ of sulphate saturation). The aggregated PGA was collected by centrifugation (5000 g, 35 min, $\left.4^{\circ} \mathrm{C}\right)$, dissolved in $10 \mathrm{mM}$ phosphate buffer $(\mathrm{pH}$ 8.0 ), dialyzed against the same buffer and the enzyme solution was applied to a DEAE-fractogel EMD 6500(S) column. The elution was carried out with the same buffer and the fractions having the activity of PGA were pooled and ultrafiltrated on Amicon 8010.

Protein concentrations were determined by means of BCA Protein assay kit (Pierce, Rockford, Ill). Bovine serum albumin was used as a standard.

\section{MALDI-TOF Mass Spectrometry}

The subunits of the purified PGA were separated by 12\% SDS-PAGE electrophoresis. Coomassie Blue-stained protein bands were cut out and digested "in gel" with a sequencing grade trypsin (Promega). The generated peptides were extracted from the gel and measured by 
MALDI-TOF MS as described earlier [36]. Positive ion MALDI mass spectra were measured on a Bruker BIFLEX reflectron time-of-flight mass spectrometer (Bruker Daltonics, Bremen, Germany) equipped with a gridless delayed extraction ion source, and a nitrogen laser $(337 \mathrm{~nm})$. Instrument was calibrated externally with a PepMix calibration kit (Bruker Daltonics). Samples of peptides $(1 \mu \mathrm{l})$ deposited and dried on target were overlaid with $1 \mu \mathrm{l}$ of diluted matrix $\alpha$-cyano-4hydroxy-cinnamic acid (one volume of saturated solution in methanol mixed with two volumes of $50 \%$ methanol and $0.3 \%$ trifluoroacetic acid (TFA)). All the measured masses are monoisotopic $\mathrm{M}+\mathrm{H}$ adduct ions.

For determination of the $\mathrm{N}$-terminuses, proteins were labelled at their N-terminuses with 4-sulfophenyl-isothiocyanate reagent $\left(10 \mathrm{mg} \mathrm{ml}^{-1}\right.$ of SPITC in $20 \mathrm{mM}$ $\mathrm{NaHCO}_{3}$ ) using modified protocol [37]. $10 \mu \mathrm{l}$ of the reagent were added to the dry protein. Immediately after 30 min incubation at $56^{\circ} \mathrm{C}$, the loading sample buffer was added and the samples were treated according to the conventional protocol for SDS-PAGE electrophoresis. The separated proteins were digested with trypsin according to the standard protocol [36]. Before measurement the peptides were desalted as follows: the peptides were deposited on target, dried on air, overlaid with CCA matrix $\left(5 \mathrm{mg} \mathrm{ml}^{-1}\right.$ in $0.1 \%$ TFA, $50 \%$ acetonitrile), and washed with $5 \mu \mathrm{l}$ of $0.1 \%$ TFA for $5-10 \mathrm{~s}$. The derivatized peptide was sequenced by MALDI TOFTOF tandem mass spectrometry (Ultraflex III, Bruker Daltonics) to confirm the $\mathrm{N}$-terminal sequence.

\section{Kinetic parameters determination and kinetically controlled syntheses}

Kinetic parameters of PGAs for penicillin G were determined by titration of phenylacetic acid with $0.01 \mathrm{M}$ $\mathrm{NaOH}$ using an autotitrator (Radiometer, Copenhagen, Denmark) at $37^{\circ} \mathrm{C}$. Kinetic parameters for NIPAB were determined by spectrophotometer, as described above. The relationship between the initial rate of the reaction and substrate concentration $(1-2000 \mu \mathrm{M})$ was determined using the Michaelis-Menten equation and a nonlinear regression program (Enzfitter, Elsevier Biosoft). To calculate $k_{\text {cat }}$ of the purified hPGA $\mathrm{A}_{\mathrm{Ec}}$, molecular weights of 86.4 (the enzyme with $\alpha_{2}$ ) and 88.4 (the enzyme with $\alpha_{1}$ ) $\mathrm{kDa}$ in a ratio 2 to 1 were used. The densities of the subunit bands in SDS-PAGE gel were evaluated using Image analysis by Intelligent Quantifier program (BioImage, Ann Arbor, Mich).

A kinetically controlled enzymatic synthesis of cephalexin, ampicillin or amoxicillin was carried out according to [24]. The reaction was catalyzed by the purified PGAs in $0.05 \mathrm{M}$ potassium phosphate buffer ( $\mathrm{pH}$ 7.0) at $30^{\circ} \mathrm{C}$. The initial concentration of activated acyl donor (D-phenylglycine amide, D-p-hydroxyphenylglycine amide) was $15 \mathrm{mM}$ and the concentration of an appropriate $\beta$-lactam nucleophile (7-ADCA or 6-APA) was 25 $\mathrm{mM}$. All reactants were monitored in time by HPLC analysis and the initial rates of formation of the antibiotics and the hydrolysis of acyl donors were determined. The $\mathrm{S} / \mathrm{H}$ ratio was calculated from the initial rates measured in the experiment.

\section{Effect of $\mathrm{pH}$ and temperature on enzyme activity}

The temperature optimum for the activity was determined by measuring penicillin $\mathrm{G}$ hydrolysis in the range of temperatures $20-60^{\circ} \mathrm{C}$. The thermal stability of PGAs was determined by incubation of the purified enzymes for $30 \mathrm{~min}$ in the range of temperatures $20-70^{\circ} \mathrm{C}$ and assaying of the remaining activity at $37^{\circ} \mathrm{C}$ with penicillin $\mathrm{G}$ at $\mathrm{pH}$ optima 8.0 and 7.5 for $\mathrm{PGA}_{\mathrm{Ec}}$ and $\mathrm{hPGA} \mathrm{Ec}_{\mathrm{Ec}}$, respectively. The effect of $\mathrm{pH}$ on the activity of the enzyme was determined with penicillin $\mathrm{G}$ as the substrate at $37^{\circ} \mathrm{C}$ in Britton-Robinson buffer $(40 \mathrm{mM}$ $\mathrm{H}_{3} \mathrm{PO}_{4}, 40 \mathrm{mM}$ acetic acid and $40 \mathrm{mM} \mathrm{H}_{3} \mathrm{BO}_{3}$, the required $\mathrm{pH}$ was adjusted by $10 \% \mathrm{NaOH}$ ) in the range of $\mathrm{pH} 4-10$. The $\mathrm{pH}$-stability was determined by incubation of the enzyme sample at a given $\mathrm{pH}$ (ranging from 3-10, Britton-Robinson buffer) for $60 \mathrm{~min}$ at room temperature. Remaining activity was assayed at $37^{\circ} \mathrm{C}$ with penicillin $\mathrm{G}$ at $\mathrm{pH}$ optima 8.0 and 7.5 for $\mathrm{PGA}_{\mathrm{Ec}}$ and $\mathrm{hPGA}_{\mathrm{Ec}}$, respectively.

\section{Acknowledgements}

We thank Jaroslav Maršálek for technical assistance. This work is supported by Institutional Research Concept No. AV0Z502090.

\section{Authors' contributions}

HM and RV carried out the molecular genetic studies and participated in the experiments with bioreactor cultivations. ZM carried out the purification of enzyme. JS performed Maldi-TOFF MS. HM and PK designed the research and wrote the manuscript. All authors read and approved the final manuscript.

\section{Competing interests}

The authors declare that they have no competing interests.

Received: 28 April 2009

Accepted: 3 February 2010 Published: 3 February 2010

\section{References}

1. Rajendhran J, Gunasekaran P: Recent biotechnological interventions for developing improved penicillin G acylases. J Biosci Bioeng 2004, 97:1-13.

2. Sobotková L, Plháčková K, Kyslík P, Vojtíšek V: Czech Patent No. 278516. 1993.

3. Kutzbach C, Rauenbusch E: Preparation and general properties of crystalline penicillin acylase from Escherichia coli ATCC 11105. HoppeSeylers Z Physiol Chem 1974, 354:45-53.

4. Konstantinovic M, Marjanovic N, Ljubijankić G, Glisin V: The penicillin amidase of Arthrobacter viscosus(ATCC 15294). Gene 1994, 143:79-83.

5. Robak M, Szewczuk A: Penicillin amidase from Proteus rettgeri. Acta Biochim Pol 1981, 28:275-284.

6. Barbero JL, Buesa JM, González de Buitrago G, Méndez E, Péz-Aranda A, García JL: Complete nucleotide sequence of the penicillin acylase gene from Kluyvera citrophila. Gene 1986, 49(1):69-80. 
7. Senthivel SG, Pai JS: Purification of penicillin acylase of Bacillus megaterium. Biotechnol Tech 1996, 10:611-614.

8. Verhaert RM, Riemens AM, Laan van der JM, van Duin J, Quax WJ: Molecular cloning and analysis of the gene encoding the thermostable penicillin G acylase from Alcaligenes faecalis. Appl Environ Microbiol 1997, 63:3412-3418.

9. Cheng T, Chen M, Zheng H, Wang J, Yang S, Jiang W: Expression and purification of penicillin $G$ acylase enzymes from four different microorganisms and a comparative evaluation of their synthesis/hydrolysis ratios for cephalexin. Protein Expression Purif 2006, 46:107-113.

10. Bruggink $A$, Roos EC, de Vroom E: Penicillin acylase in the industrial production of $\beta$-lactam antibiotics. Org Process Res Dev 1998, 2:128-133.

11. Gabor EM, Janssen DB: Increasing the synthetic performance of penicillin acylase PAS2 by structure-inspired semi-random mutagenesis. Protein Eng Des Sel 2004, 17(7):571-579.

12. Ignatova Z, Wischnewski F, Notbohm H, Kasche V: Pro-sequence and $\mathrm{Ca}^{2}$ ${ }^{+}$-binding: Implications for folding and maturation of Ntn-hydrolase penicillin amidase from E. coli. J Mol Biol 2005, 348:999-1014.

13. Hewitt L, Kasche V, Lummer K, Lewis RJ, Murshudov GN, Verma CS, Dodson GG, Wilson KS: Structure of a slow processing precursor penicillin acylase from Escherichia coli reveals the linker peptide blocking the active-site cleft. J Mol Biol 2000, 302(4):887-898.

14. Kasche V, Lummer K, Nurk A, Piotraschke E, Rieks A, Stoeva S, Voelter W: Intramolecular autoproteolysis initiates the maturation of penicillin amidase from Escherichia coli. Biochim Biophys Acta 1999, 1433:76-86.

15. Yang Y, Biedendieck R, Wang W, Gamer M, Malten M, Jahn D, Deckwer WD: High yield recombinant penicillin $\mathrm{G}$ amidase production and export into the growth medium using Bacillus megaterium. Microb Cell Fact 2006, 5:36.

16. Jahic M, Veide A, Charoenrat T, Teeri T, Enfors SO: Process technology for production and recovery of heterologous proteins with Pichia pastoris. Biotechnol Prog 2006, 22:1465-1473.

17. Daly R, Hearn MT: Expression of heterologous proteins in Pichia pastoris: a useful experimental tool in protein engineering and production. $J \mathrm{Mol}$ Recognit 2005, 18(2):119-138.

18. Gurkan C, Ellar DJ: Recombinant production of bacterial toxins and derivatives in the methylotrophic yeast Pichia pastoris. Microb Cell Fact 2005, 4:33.

19. Choi YJ, Miguez CB, Lee BH: Characterization and heterologous gene expression of a novel esterase from Lactobacillus casei CL96. Appl Environ Microbiol 2004, 70(6):3213-3221.

20. Ljubijankić G, Storici F, Glišin V, Bruschi CV: Synthesis and secretion of Providencia rettgeri and Escherichia coli heterodimeric penicillin amidases in Saccharomyces cerevisiae. Gene 1999, 228:225-232.

21. Ljubijankić G, Gvozdenović J, Ševo M, Degrassi G: High-level secretory expression of penicillin amidase from Providencia rettgeri in Saccharomyces cerevisiae: purification and characterization. Biotechnol Prog 2002, 18:330-336.

22. Ševo M, Degrassi G, Skoko N, Venturi V, Ljubijankić G: Production of glycosylated thermostable Providencia rettgeri penicillin $\mathrm{G}$ amidase in Pichia pastoris. FEMS Yeast Res 2002, 1:271-277.

23. Senerovic L, Stankovic N, Pizzo P, Basso A, Gardossi L, Vasiljevic B, Ljubijankić G, Tisminetzky S, Degrassi G: High-level production and covalent immobilization of Providencia rettgeri penicillin $\mathrm{G}$ acylase (PAC) from recombinant Pichia pastoris for the development of a novel and stable biocatalyst of industrial applicability. Biotechnol Bioeng 2006, 93:344-354.

24. Gabor EM, de Vries EJ, Janssen DB: A novel penicillin acylase from the environmental gene pool with improved synthetic properties. Enzyme Microb Technol 2005, 36:182-190.

25. Valešová R, Hollerová-Sobotková L, Štěpánek V, Kyslík P: Optimisation of the host-plasmid interaction in the recombinant Escherichia coli strains overproducing penicillin G acylase. Enzyme Microb Technol 2004, 35:74-80.

26. Plhačková K, Štěpánek V, Kyslík P, Sobotková L: Czech Patent No. 282712. 1997.

27. Böck A, Wirth R, Schmid G, Schumacher G, Lang G, Buckel P: The penicillin acylase from Escherichia coli ATCC 11105 consists of two dissimilar subunits. FEMS Microbiol Lett 1983, 20:135-139.

28. Ignatova Z, Stoeva S, Galunsky B, Hörnle C, Nurk A, Piotraschke E, Voelter W, Kasche V: Proteolytic processing of penicillin amidase from Alcaligenes faecaliscloned in Escherichia coli yields several active forms. Biotechnol Lett 1998, 20:977-982.
29. Zhou Z, Zhang AH, Wang JR, Chen ML, Li RB, Yang S, Yuan ZY: Improving the specific synthetic activity of a penicillin $\mathrm{G}$ acylase using DNA family shuffling. Acta Biochim Biophys Sin 2003, 35:573-579.

30. Erarslan A, Terzi I, Guray A, Bermek E: Purification and kinetics of penicillin $\mathrm{G}$ acylase from a mutant strain of Escherichia coli ATCC 11105. J Chem Technol Biotechnol 1991, 51:27-40.

31. Cai G, Zhu S, Yang S, Zhao G, Jiang W: Cloning, overexpression, and characterization of a novel thermostable penicillin $\mathrm{G}$ acylase from Achromobacter xylosoxidans: probing the molecular basis for its high thermostability. Appl Environ Microbiol 2004, 70:2764-2770.

32. Sobotková L, Štěpánek V, Plháčková K, Kyslík P: Development of a highexpression system for penicillin $\mathrm{G}$ acylase based on the recombinant Escherichia coli strain RE3(pKA18). Enzyme Microb Technol 1996, 19:389-397.

33. Sambrook J, Fitsch EF, Maniatis T: Molecular Cloning: A Laboratory Manual Cold Spring Harbor, Cold Spring Harbor Press 1989.

34. Balasingham $K$, Warburton $D$, Dunnill $P$, Lilly MD: The isolation and kinetics of penicillin amidase from Escherichia coli. Biochim Biophys Acta 1972, 276:250-256.

35. Weatherburn MW: Linear regression analysis of the released ammonia, determined by conversion to indophenol. Anal Chem 1967, 39:971-974.

36. Volf $P$, Skarupova $S$, Man $P$ : Characterization of the lectin from females of Phlebotomus duboscqi sand flies. Eur J Biochem 2002, 269:6294-6301.

37. Zhang X, Rogowska-Wrzesinska A, Roepstorff P: On-target sample preparation of 4-sulfophenyl isothiocyanate-derivatized peptides using AnchorChip Targets. J Mass Spectrom 2008, 43(3):346-359.

doi:10.1186/1472-6750-10-7

Cite this article as: Marešová et al:: Heterologous expression of leaderless pga gene in Pichia pastoris: intracellular production of prokaryotic enzyme. BMC Biotechnology 2010 10:7.

\section{Submit your next manuscript to BioMed Central and take full advantage of:}

- Convenient online submission

- Thorough peer review

- No space constraints or color figure charges

- Immediate publication on acceptance

- Inclusion in PubMed, CAS, Scopus and Google Scholar

- Research which is freely available for redistribution

Submit your manuscript at www.biomedcentral.com/submit
Biomed Central 